and acoustic oscillations, electronics and radiocommunication. The papers are published in the language in which they were submitted by the authors. The numbers of papers in the four sections, with those in English indicated in brackets, are: $14(9), 21(8), 8(5)$ and $16(10)$. The publication provides an interesting survey of the many scientific and technical developments in this field in the halfcentury following Marconi's first successful demonstration of wireless signalling.

\section{New Zealand Earthquakes during June}

During June, five strong earthquakes were registered on the New Zealand seismographs at Arapuni, Auckland, Christchurch, Kaimati, New Plymouth, Tuai and Wellington. The one on June 28 was that which destroyed the Japanese city of Fukui, and that on June 29 was felt at Apia with Modified Mercalli Scale 5. In addition, twenty-three earthquakes and earth tremors occurred within $10^{\circ}$ of Wellington. The greatest two of these both occurred on June 19 and were felt extensively in South Island but particularly near Bruce Bay with Modified Mercalli Scale 6.

\section{The Night Sky in November}

NEw moon occurs on Nov. 1d. 06h. 02m., U.T., and full moon on Nov. 16d. 18h. 3lm. The following conjunctions with the moon take place: Nov. 3d. 17h., Mars $2^{\circ}$ N.; Nov. 4d. 20h., Jupiter $4^{\circ}$ N.; Nov. 24 d. $02 \mathrm{~h}$., Saturn $3^{\circ}$ S. ; Nov. $28 \mathrm{~d}$. 06h., Venus $2^{\circ} \mathrm{N}$. Mercury rises at $5 \mathrm{~h} .10 \mathrm{~m}$. and $5 \mathrm{~h} .49 \mathrm{~m}$. on Nov. 1 and 15, respectively, and can be seen in the eastern sky. The planet reaches its greatest easterly elongation on Nov. 4. At the end of the month Mercury rises only half an hour before sunrise and is then too close to the sun for observation. Venus rises at $3 \mathrm{~h} .15 \mathrm{~m} ., 3 \mathrm{~h} .55 \mathrm{~m}$. and $4 \mathrm{~h} .40 \mathrm{~m}$. at the beginning, middle and end of the month, respectively, and can be seen in the morning hours, stellar magnitude $-3.5 ; 0.75$ to 0.84 of the illuminated disk is visible. Mars is too close to the sun to be favourably observed, setting about 1 hours after the sun throughout the month. Jupiter sets at $18 \mathrm{~h} .55 \mathrm{~m}$., $18 \mathrm{~h}$. $10 \mathrm{~m}$. and $17 \mathrm{~h} .25 \mathrm{~m}$. at the beginning, middle and end of the month, respectively, and can be seen low in the western sky; but it is not favourably placed for observation through the greater portion of the month. Saturn, in the constellation of Leo, rises at $0 \mathrm{~h} .45 \mathrm{~m}$., $0 \mathrm{~h} .$, and $23 \mathrm{~h}$. at the beginning, middle and end of the month, respectively, and is visible throughout the morning hours, stellar magnitude $0 \cdot 9$. Occultations of stars brighter than magnitude 6 are as follow: Nov. 8d. 17h. 51.1m., 35 Capr. $(D)$; Nov. 19d. 0lh. 13.1m., 112B Auri. $m,(R) ; D$ and $R$ refer to disappearance and reappearance, respectively, and the latitude of Greenwich is assumed. A total eclipse of the sun takes place on Nov. 1. The eclipse is invisible at Greenwich, but is visible over large portions of the southern hemisphere. The central line passes through lat. $+3^{\circ} 42^{\prime}$, long. - $22^{\circ} 03^{\prime}$, at the beginning of the eclipse and ends at lat. $-43^{\circ} 23^{\prime}$, long. $-165^{\circ} 27^{\prime}$.

\section{Announcements}

THe Lord President of the Council has made the following appointments to the Advisory Council for Scientific Research: Mr. James Bowman, vicepresident of the National Union of Mineworkers, and a member of the T.U.C. Scientific Advisory Com. mittee; Mr. E. Fletcher, secretary of the Research and Economic Department of the T.U.C.; and Dr. H. W. H. Warren, managing director of Associated Electrical Industries, Ltd.

THE Cambridge Philosophical Society announces that the adjudicators for the Hopkins Prize have made the following awards : for the period 1939-42, to Prof. H. J. Bhabha, for investigations on the theory of elementary particles; for the period 1942-45, to Dr. C. F. Powell, for experimental investigations in nuclear physics, including development of the photographic plate technique for the study of nuclear reactions.

AN Eddington Prize of 50,000 Belgian francs is being offered by the Institut International des Sciences Theoriques for an exposition and critique of the conceptions of Eddington concerning "The Philosophy of Physical Science". The committee of award consists of Dr. I. Dockx, director of the Institute ; Prof. L. de Broglie (Paris); Prof. Th. de Donder (Brussels) ; Prof. F. Gonseth (Zurich); and Prof. E. A. Milne (Oxford). Memoirs (five copies) must be submitted to the secretariat of the Institut International des Sciences Theoriques, 221 avenue de Tervueren, Brussels, before December 31, 1950. Participants must sign their memoirs by a device, and include a sealed envelope containing name and address.

THe Atomic Scientists' Association is holding its annual conference at the Beaver Fiall, Garlick Hill, London, E.C.4, on October 30. There will be two sessions, the first from 2.30 to 5 p.m., and the second from 7 p.m. to 9.30 p.m. The first session is concerned with "Atomic Energy and Society", and speakers will include Prof. P. M. S. Blackett on atomic weapons, Sir George Thomson on international control, Prof. N. F. Mott on national policy, and Prof. M. H. L. Pryce on the constructive applications of atomic energy. In the evening, speakers will include Sir Henry Dale, Prof. R. E. Peierls and Prof M. L. Oliphant on the position of scientific men with regard to atomic energy and related problems. The hon. general secretary, Dr. F. C. Champion, will conclude with an outline of the future policy of the Association.

A SERIEs of lectures for schools, which began on October 20, has been organised by the Institution of Civil Engineers, the Institution of Electrical En. gineers and the Institution of Municipal Engineers, in co-operation with the Education Officer of the London County Council. The lectures are being given at the Institution of Civil Engineers, Great George Street, Westminster, S.W.1, and deal with such subjects as railway transport, water and electricity supply, tunnelling, telecommunications, etc. These lectures, which can be given either at individual schools or for groups of schools, are supplemented by the annual Christmas lectures to boys at the Institution of Civil Engineers. For Christmas 1948 the subject will be "Big Ships and their Docks"; three lectures will be given: "Building Big Ships"; "Running and Navigating a Ship"; and "Con. structing a Dock".

Erratum.-In "Dielectric Properties of Mixed Barium and Strontium Titanates at 10,000 Mc./s." printed in Nature of October 23, p. 655, Fig. 2 should be rotated $90^{\circ}$ clockwise ; the descriptions of the axes remain as they are. 